\section{A NESTLINE DRAMA}

\section{by JOHN LANE*}

On June 12, 1972, I was banding bluebirds east of Camp Hughes, Manitoba, on the Canadian Pacific Railway. When I arrived at Nestbox No. 783, known to house a brood of Mountain Bluebirds, a storm of frenzied food-calls met me as I removed the top to band the fledglings; it was obvious that these young were close to starving, which raised the question as to the whereabouts of the parents. Experience had taught me that frantically hungry baby bluebirds could mean both adult providers had perished, in which case it would be up to me to find alternative board and room for the foundlings; or in an extremity take them home and hand raise them. Having banded all seven, I found only five bands remained on the string, so I continued east till I finished up.

In an elapsed time of just over one half hour I was back to No. 783. I was climbing out of the car to investigate this nestbox once more, when a pair of Eastern Bluebirds flew into view, the female carrying a large beakfull of building material and the male in close attendance. The mother bird went directly to the nesthole, peered in, then went in and remained there for a full minute. Her entrance evoked another storm of frantic cries from the seven young, but she paid them no heed, and it was at once clear that this was no shy little Eastern female, furtively carrying nesting material to a chosen site, "in secret and apart"; rather this was a harried creature intent on preparing a new nest for her imminent clutch of eggs at the earliest possible moment. Without doubt this pair had been evicted from their previous home just as the eggs were due to be laid.

In any case, extreme urgency was evident in their every action; the female would hurtle from the nestbox, drop down to the ditch, seize whatever was handy in the way of grass and hasten

*1701 Lorne Avenue,

Brandon, Manitoba. back to the nest. The male too wa seized with the need for haste, and I sav him carry material and dump it throug the nesthole, where it cascaded down t the starving babies. The fact that I stoor within 10 feet of the nestbox, in fu view of the working birds for som minutes, did not divert the pair for moment: time was of the extreme essenc and they had none of it for mere man

By now it was certain that the Moun tain parents were out of the picture, an the seven young were without support so I removed them from their nest. The were a bedraggled lot, covered wit building debris and some with bits o grass protruding from their mouths frantic with hunger, they had tried $t$ ingest whatever came to hand. I let three of these babies in Nestbox No. 8 . nearby, where a pair of Mountains wer raising three young; the other four wen home with me, where we quickly fed an comforted them. The following day w left these with another Mountain coupl on the Hooke Ranch line; they had fou of their own. Both at this nest and a Nestbox No. 85, the original youn were of a similar age to the orphans.

Relieved of the nuisance of trying t build a nest on top of seven squirmin foreigners, the Eastern female quickl got the job done. On June 14, two day after their arrival, I visited this nes again late in the day and found already held two eggs - confirming th need for haste in getting the nest buil One important question remains wit me: how did this Eastern pair know the there were no Mountain parents $t$ dispute their takeover of this nestbox? may be that they had been present fo some time, quietly watching an listening for any sign of the origin owners, before they made their move $t$ take over.

\section{JACK LANE}

\section{In Reader's Digest}

"The Man Who Brought Th Bluebirds Back" is the title of an in teresting six-page story about Jac Lane in the September, 1973, issue Reader's Digest. 